\title{
Persistence of Overseeded Cool-Season Grasses in Bermudagrass Turf
}

\author{
Thomas Serensits, ${ }^{1}$ Matthew Cutulle, ${ }^{2}$ and Jeffrey F. Derr ${ }^{2}$ \\ ${ }^{1}$ Center for Sports Surface Research, Department of Crop and Soil Sciences, The Pennsylvania State University, \\ 212 Agricultural Sciences and Industries Building, University Park, PA 16802, USA \\ ${ }^{2}$ Department of Plant Pathology, Physiology, and Weed Science, Virginia Tech, \\ Hampton Roads Agricultural Research and Extension Center, Virginia Beach, VA 23455, USA
}

Correspondence should be addressed to Jeffrey F. Derr, jderr@vt.edu

Received 30 June 2011; Accepted 11 September 2011

Academic Editor: Kassim Al-Khatib

Copyright (๑) 2011 Thomas Serensits et al. This is an open access article distributed under the Creative Commons Attribution License, which permits unrestricted use, distribution, and reproduction in any medium, provided the original work is properly cited.

Cool-season grass species are commonly overseeded into bermudagrass turf for winter color. When the overseeded grass persists beyond the spring; however, it becomes a weed. The ability of perennial ryegrass, Italian (annual) ryegrass, intermediate ryegrass, and hybrid bluegrass to persist in bermudagrass one year after seeding was determined. Perennial ryegrass, intermediate ryegrass, and Italian ryegrass produced acceptable ground cover in the spring after fall seeding. Hybrid bluegrass did not establish well, resulting in unacceptable cover. Perennial ryegrass generally persisted the most one year after seeding, either because of summer survival of plants or because of new germination the following fall. Plant counts one year after seeding were greater in the higher seeding rate treatment compared to the lower seeding treatment rate of perennial ryegrass, suggesting new germination had occurred. Plant counts one year after seeding plots with intermediate ryegrass or Italian ryegrass were attributed primarily to latent germination and not summer survival. Applications of foramsulfuron generally did not prevent overseeded species stand one year after seeding, supporting the conclusion of new germination. Although quality is less with intermediate ryegrass compared to perennial ryegrass, it transitions out easier than perennial ryegrass, resulting in fewer surviving plants one year later.

\section{Introduction}

Bermudagrass (Cynodon spp.) is the primary turfgrass grown on athletic fields and golf courses in regions ranging from the transition zone of the United States to the tropics of the world [1]. The density, color, texture, and summertime vigor of bermudagrass has led to the adaptation of many cultivars for use on home lawns, leisure areas, and athletic fields [2]. While bermudagrass typically provides an ideal turf during the summer, an underlining negative trait of bermudagrass is its winter dormancy period, especially in the transition zone where cold temperatures linger for several months. Overseeding with cool-season grasses is a cultural management technique commonly used to maintain both aesthetic and playability features in dormant bermudagrass during the winter $[3,4]$.
Overseeding was first practiced on golf courses in the 1930s after initially being used in pasture grasses [5]. Overseeding techniques have evolved since the 1930s; however, the goals remain the same: to provide green turf during bermudagrass dormancy and then transition to bermudagrass in the late spring. If the overseeded grass persists into the summer, it may reduce bermudagrass density and overall turf quality. The cool-season grass selected for overseeding largely determines the success or failure of the overseeding process. There are two transitional phases to consider when selecting a cool-season grass for overseeding: ease of fall establishment of the overseeded grass and ease of spring transition back to bermudagrass [6]. Each species of cool-season grass has both positive and negative attributes that affect its overseeding performance. In the past, Italian ryegrass (Lolium multiflorum Lam.), commonly referred to 
as annual ryegrass, was the overseeding species of choice because of its rapid germination and establishment. However, Italian ryegrass is coarse-textured, requires frequent mowing, and has inadequate cold and heat tolerance [1]. Italian ryegrass also tends to have a less desirable, lighter green color than other overseeding species, resulting in lower quality rating [7]. Improved Italian ryegrass cultivars, such as "Panterra" [8] were bred for improved quality as well as enhanced spring transition. Compared to Italian ryegrass, perennial ryegrass (Lolium perenne L.) has a finer leaf texture, darker green color, and generally produces a higher quality turf. Consequently, it is often used as both an overseeding species in warm climates and as a year-round turf in cooler climates. Perennial ryegrass's popularity has led to the breeding of heat-tolerant, drought-tolerant, and disease-resistant cultivars. While these are generally desirable attributes, perennial ryegrass will often survive the summer and persist as a perennial weed in overseeded bermudagrass [9]. Italian ryegrass is listed as either a winter annual, biennial, or occasionally a perennial while perennial ryegrass is described as a short-lived perennial [10]. Intermediate ryegrass (L. perenne $\mathrm{x} L$. multiflorum), is a hybrid between perennial and Italian ryegrass [1].

Hybrid bluegrass (Poa pratensis L. x Poa arachnifera Torr.) was created by crossing Kentucky bluegrass (Poa pratensis L.) and Texas bluegrass (Poa arachnifera Torr.) [11]. Hybrid bluegrass has the agronomic qualities of Kentucky bluegrass such as dark green color, brown patch (Rhizoctonia solani) resistance, and utility, but was bred to have increased heat and drought tolerance exhibited by Texas bluegrass. Its ability to survive heat and drought may be problematic when used as an overseeded grass when transitioning back to bermudagrass in late spring. However, if hybrid bluegrass transitions into dormancy during the heat of the summer and then returns to normal growth in the fall, it may be able to coexist with bermudagrass, providing a two-grass system that does not require overseeding each year.

Overseeded cool-season grasses persisting through the summer may become a weed problem the following fall and winter if no overseeding is conducted. The overseeded grass would be clumpy and unevenly distributed throughout the bermudagrass stand. Currently, little information is available on the long-term persistence of overseeded grasses in bermudagrass.

Environmental conditions and cultural practices greatly affect the spring-time transition to bermudagrass regardless of which overseeded species is used. Elevated temperatures and low rainfall in fall may adversely affect overseeded grass establishment unless supplemented with appropriate irrigation. Additionally, low temperatures and high rainfall in late spring and early summer of the following year may allow the overseeded grass to persist well past bermudagrass green-up. Cultural practices such as planting at appropriate seeding rates, fertility management, thatch removal, aeration, irrigation management, and mowing frequency each affect ease of transition [12, 13]. Current recommended ryegrass overseeding rates in the coastal mid-Atlantic region of the United States are approximately $400 \mathrm{~kg}$ per hectare [14]. Overseeding in the Mid-Atlantic with ryegrass is typically done in October. Most overseeding is performed in the fall before bermudagrass goes dormant. Additional information is needed on herbicides that will selectively remove overseeded cool-season grasses from bermudagrass without damage to this warm-season turf species.

Common herbicides that control ryegrass species include the class of acetyl CoA carboxylase (ACCase) inhibitors such as diclofop, fluazifop, and fenoxaprop. However, because of the ability of ryegrass species to either metabolize these compounds or express an alternative ACCase enzyme, resistance has developed in multiple ecotypes [15]. In addition, bermudagrass does not tolerate most chemicals in this class. Therefore, alternative modes of actions have been considered. Beam et al. [16] evaluated the ability of three ALS-inhibiting herbicides (chlorsulfuron, primisulfuron, and nicosulfuron) to control Italian ryegrass in tall fescue. The researchers found that nicosulfuron offered the most effective control while producing the least amount of turfgrass injury. We evaluated another ALS-inhibiting herbicide, foramsulfuron, for its ability to eliminate overseeded grasses during the spring-summer transition period as well as reducing persistence of ryegrass species one year after seeding.

Many turfgrass managers face the challenge of transitioning from overseeded cool-season grasses to bermudagrass each spring. If the removal of the overseeded grass is done too early, brown, dormant bermudagrass will be visible. If the overseeded grass is allowed to remain and persist into the summer before removal, bermudagrass growth is stunted. Lowering mowing heights, verticutting, aerifying, fertilizing, and reducing irrigation to encourage bermudagrass growth are practices that help improve the spring transition from the cool-season grass. Additionally, chemical removal strategies and species selection are key factors in determining the success of the overseeding process. In our studies we evaluated how seeding rate and timing of foramsulfuron affects overseeded turf cover for hybrid bluegrass, annual ryegrass, and perennial ryegrass. Additionally, we compared an intermediate ryegrass, expected to be a short-lived ryegrass cultivar, to a perennial ryegrass cultivar that would have greater heat tolerance. The goal of this research was to determine the overseeded species that establishes best in the fall while easily transitioning to bermudagrass in the summer without persistence into the following fall.

\section{Materials and Methods}

2.1. General Conditions. Two field experiments were established in 2004 at the Hampton Roads Agricultural Research and Extension Center in Virginia Beach, VA; USA One experiment compared a perennial ryegrass blend and an intermediate ryegrass cultivar in their ability to transition with and without applying the herbicide foramsulfuron. The other experiment evaluated the impact of foramsulfuron timing on Italian ryegrass, intermediate ryegrass, and hybrid bluegrass. Each experiment was repeated in 2005. The two trials for each experiment were established using a factorial arrangement of treatments in a randomized complete block design with four replications. The overseeded grasses were 
seeded directly to the bermudagrass stand without site preparation using a drop spreader. Supplemental irrigation was used during the establishment period. Foramsulfuron was applied using a $\mathrm{CO}_{2}$ powered backpack sprayer delivering $230 \mathrm{~L} / \mathrm{ha}$ at $206 \mathrm{kPa}$ using a four nozzle boom containing 8003 flat fan nozzle tips. Plots were $1.8 \mathrm{~m}$ by $3.0 \mathrm{~m}$. Plots were mowed at $3.2 \mathrm{~cm}$ from September to November and 2.2 from March until August. Percent cover for the overseeded grasses was recorded in November, February, and June for each trial of both experiments. Plant stand was recorded in late fall of the second year for each trial.

\subsection{Comparison of Two Ryegrass Species for Overseeding.} These field experiments were conducted in "Tifway 419" bermudagrass in 2004 and repeated in an adjacent field of Tifway 419 bermudagrass in 2005. Cool-season grasses were seeded in October 15, 2004 and October 17, 2005, respectively, for trial one and trial two of this experiment and included an overseeding blend of perennial ryegrasses ("Charger II," "Manhattan 4," and "Citation Fore") and intermediate ryegrass ("Transist 2200"). The ryegrass cultivars were seeded at 224 and $448 \mathrm{~kg} \mathrm{ha}^{-1}$. Foramsulfuron $(0.29 \mathrm{~kg}$ ai $/ \mathrm{ha})$ was applied to half of the plots on April 19, 2005 in trial one and April 20, 2006 in trial two to determine its impact on the cool-season grasses for transition to bermudagrass. The 2005 application was made under the following conditions: $17^{\circ} \mathrm{C}$ air temperature, $47 \%$ relative humidity, $5 \%$ cloud cover, soil temperature $14^{\circ} \mathrm{C}$, and $30 \%$ bermudagrass green-up. The 2006 application was made under the following conditions: $17 \mathrm{C}$ air temperature, 50\% relative humidity, $0 \%$ cloud cover, soil temperature $14^{\circ} \mathrm{C}$, and $50 \%$ bermudagrass green-up.

2.3. Overseeding Species/Herbicide Timing Experiment. This experiment was conducted on "Tifway 419" bermudagrass in 2004 and repeated in 2005 in a stand of "Yukon" bermudagrass. The overseeded grasses tested were "Transist 2200" intermediate ryegrass, "Panterra" Italian ryegrass, and "Thermal Blue" hybrid bluegrass. Both ryegrasses were seeded in October 15, 2004 and October 17, 2005 and hybrid bluegrass was seeded in September 15, 2004 and September 15,2005 , respectively, for trial one and trial two of this experiment. Hybrid bluegrass was seeded ine month earlier due to its slower germination rate compared to ryegrass. The ryegrasses were seeded at a rate of $224 \mathrm{~kg} \mathrm{ha}^{-1}$. Hybrid bluegrass was seeded at $101 \mathrm{~kg} \mathrm{ha}^{-1}$. Foramsulfuron $(0.29 \mathrm{~kg}$ ai ha ${ }^{-1}$ ) was applied at three different times in the spring. The first application in 2005 was made in March 30 under the following conditions: $11^{\circ} \mathrm{C}$ air temperature, $85 \%$ relative humidity, $100 \%$ cloud cover, soil temperature $12^{\circ} \mathrm{C}$, and $5 \%$ bermudagrass green-up. The second application in 2005 was made in April 19 under the following conditions: $23^{\circ} \mathrm{C}$ air temperature, $47 \%$ relative humidity, $5 \%$ cloud cover, soil temperature $14^{\circ} \mathrm{C}$, and $30 \%$ bermudagrass green-up. The third application in 2005 was made in May 2 under the following conditions: $17^{\circ} \mathrm{C}$ air temperature, $64 \%$ relative humidity, $50 \%$ cloud cover, soil temperature $17^{\circ} \mathrm{C}$, and $80 \%$ bermudagrass green-up. The first application in 2006 was made in March 31 under the following conditions: $21^{\circ} \mathrm{C}$ air temperature, $27 \%$ relative humidity, $10 \%$ cloud cover, soil temperature $18^{\circ} \mathrm{C}$, and $10 \%$ bermudagrass green-up. The second application in 2006 was made in April 20 under the following conditions: $17^{\circ} \mathrm{C}$ air temperature, $50 \%$ relative humidity, $0 \%$ cloud cover, soil temperature $14^{\circ} \mathrm{C}$, and $50 \%$ bermudagrass green-up. The third application in 2006 was made in May 2 under the following conditions: $15^{\circ} \mathrm{C}$ air temperature, $46 \%$ relative humidity, $50 \%$ cloud cover, soil temperature $17^{\circ} \mathrm{C}$, and $75 \%$ bermudagrass green-up.

2.4. Data Analysis. Main plot factors that fixed effects were ryegrass cultivar (intermediate or perennial), herbicide (foramsulfuron or no foramsulfuron), trial (2004 or 2005), and seeding rate $\left(224\right.$ or $448 \mathrm{~kg} \mathrm{ha}^{-1}$ ). Main plot factors in experiment two were overseeded grass species (intermediate ryegrass, annual ryegrass, or hybrid bluegrass), trial (2004 or 2005), and foramsulfuron application date (March, April, or May). Data was subjected to ANOVA ( $\alpha=0.05)$ using mixed methodology (Statistical Analysis Software v. 9.1, Cary, NC). Since there was a significant treatment by trial interaction for both experiments, results are presented by year. Percent cover and plants per $\mathrm{m}^{2}$ were the dependent variable in all the trials.

\section{Results and Discussion}

3.1. Comparison of 2 Ryegrass Species for Overseeding. Increasing the seeding rate resulted in increased ryegrass cover in November (Table 1). Percent ryegrass cover when the plots were overseeded with $224 \mathrm{~kg} \mathrm{ha}^{-1}$ of perennial ryegrass was $78 \%$ in November, $84 \%$ in February, and 53\% in June in trial one. Comparatively, percent cover when seeded with perennial ryegrass at $448 \mathrm{~kg} \mathrm{ha}^{-1}$ rate was $83 \%$ in November, $89 \%$ in February, and $51 \%$ in June of trial one (Table 1). Significant percent cover differences were observed between the two ryegrass cultivars on the June rating date. When plots were seeded with $224 \mathrm{~kg} \mathrm{ha}^{-1}$ of intermediate ryegrass with no foramsulfuron, the percent cover was $4 \%$ in June, which was significantly less than the $53 \%$ cover observed in untreated plots seeded with perennial ryegrass. Applying foramsulfuron to plots seeded with perennial ryegrass at $224 \mathrm{~kg} \mathrm{ha}^{-1}$ reduced ryegrass cover from $53 \%$ to $28 \%$ in June of trial one. Intermediate ryegrass died naturally; therefore, no difference was observed between foramsulfuron-treated and nontreated plots in June.

Similar patterns were seen in trial two though ryegrass cover was less across most of the rating dates. This reduction in cover may be the result of less rainfall during establishment. In trial one, $5.1 \mathrm{~cm}$ of rain was recorded from October 14 through November 14, 2004. In trial two, only $0.7 \mathrm{~cm}$ ( $0.3 \mathrm{in})$ of rain was recorded from October 14 through November 14, 2005. Percent cover in perennial ryegrass plots seeded at $224 \mathrm{~kg} \mathrm{ha}^{-1}$ and $448 \mathrm{~kg} \mathrm{ha}^{-1}$ was $40 \%$ and $47 \%$, respectively on the November rating date in trial two (Table 2). Foramsulfuron did not significantly reduce percent cover in June for trial two, probably due to the low stand seen in both untreated and treated plots. Less perennial ryegrass persisted into June in trial two compared to trial one (Tables 1 and 2). This could be due to lower rainfall amounts, 
TABle 1: Percent cover of ryegrasses as affected by seeding rate, foramsulfuron application, and overseeded species in 2004 for the first experiment. ${ }^{\mathrm{a}}$

\begin{tabular}{|c|c|c|c|c|c|}
\hline \multirow{2}{*}{$\begin{array}{l}\text { Ryegrass } \\
\text { species }\end{array}$} & \multirow{2}{*}{ Foramsulfuron } & \multirow{2}{*}{ Seeding rate (kg/ha) } & \multicolumn{3}{|c|}{ Percent cover } \\
\hline & & & November & February & June \\
\hline \multirow{2}{*}{ Intermediate } & No & 224 & $75 \mathrm{~b}$ & $82 \mathrm{a}$ & $4 \mathrm{c}$ \\
\hline & No & 448 & $84 \mathrm{a}$ & $89 \mathrm{a}$ & $4 \mathrm{c}$ \\
\hline \multirow{2}{*}{ Perennial } & No & 224 & $78 \mathrm{~b}$ & $84 \mathrm{a}$ & $53 \mathrm{a}$ \\
\hline & No & 448 & $83 \mathrm{a}$ & $89 \mathrm{a}$ & $51 \mathrm{a}$ \\
\hline \multirow{2}{*}{ Intermediate } & Yes & 224 & $74 \mathrm{~b}$ & $79 \mathrm{a}$ & $2 c$ \\
\hline & Yes & 448 & $84 \mathrm{a}$ & $88 \mathrm{a}$ & $2 c$ \\
\hline \multirow{2}{*}{ Perennial } & Yes & 224 & $73 \mathrm{~b}$ & $80 \mathrm{a}$ & $28 \mathrm{~b}$ \\
\hline & Yes & 448 & $85 \mathrm{a}$ & $91 \mathrm{a}$ & $25 \mathrm{~b}$ \\
\hline
\end{tabular}

${ }^{a}$ Means within a column with the same letter are not significantly different according to the Fisher's protected least significant difference test at the 0.05 level.

TABle 2: Percent cover of ryegrasses as affected by seeding rate, foramsulfuron application, and overseeded species in 2005 for the first experiment. $^{\mathrm{a}}$

\begin{tabular}{|c|c|c|c|c|c|}
\hline \multirow{2}{*}{$\begin{array}{l}\text { Ryegrass } \\
\text { species }\end{array}$} & \multirow{2}{*}{ Foramsulfuron } & \multirow{2}{*}{ Seeding rate $(\mathrm{kg} / \mathrm{ha})$} & \multicolumn{3}{|c|}{ Percent cover } \\
\hline & & & November & February & June \\
\hline \multirow{2}{*}{ Intermediate } & No & 224 & $53 \mathrm{ab}$ & $59 \mathrm{~b}$ & $5 \mathrm{bc}$ \\
\hline & No & 448 & $58 \mathrm{a}$ & $66 \mathrm{a}$ & $2 c$ \\
\hline \multirow{2}{*}{ Perennial } & No & 224 & $40 \mathrm{c}$ & $49 \mathrm{~d}$ & $4 \mathrm{bc}$ \\
\hline & No & 448 & $47 \mathrm{~b}$ & $59 \mathrm{~b}$ & $9 a$ \\
\hline \multirow{2}{*}{ Intermediate } & Yes & 224 & $50 \mathrm{~b}$ & $57 \mathrm{bc}$ & $2 c$ \\
\hline & Yes & 448 & $55 \mathrm{ab}$ & $63 \mathrm{ab}$ & $1 \mathrm{c}$ \\
\hline \multirow{2}{*}{ Perennial } & Yes & 224 & $44 \mathrm{bc}$ & $51 \mathrm{~cd}$ & $6 \mathrm{ab}$ \\
\hline & Yes & 448 & $51 \mathrm{~b}$ & $56 \mathrm{bc}$ & $6 \mathrm{ab}$ \\
\hline
\end{tabular}

${ }^{a}$ Means within a column with the same letter are not significantly different according to the Fisher's protected least significant difference test at the 0.05 level.

since only $0.7 \mathrm{~cm}$ of rain fell from May 16 through June 2, 2006 while $5.8 \mathrm{~cm}$ fell during this period in 2005 .

More plants per $\mathrm{m}^{2}$ one year after seeding were observed in plots overseeded with perennial ryegrass than intermediate ryegrass in trial one (Table 3 ). Also, increasing the seeding rate resulted in increased plant counts one year after seeding, suggesting a degree of new germination. In study one, intermediate ryegrass plots had 10.8 and 30.5 plants per $\mathrm{m}^{2}$ when seeded at a rate 224 and $448 \mathrm{~kg} \mathrm{ha}^{-1}$, respectively. Plots seeded with $224 \mathrm{~kg} \mathrm{ha}^{-1}$ of perennial ryegrass had 60.5 plants per $\mathrm{m}^{2}$. Increasing the seeding rate to $448 \mathrm{~kg} \mathrm{ha}^{-1}$ of perennial ryegrass resulted in 170.5 plants per $\mathrm{m}^{2}$. Foramsulfuron application had a variable impact on plant counts. Typically, plots treated with foramsulfuron had fewer plants per $\mathrm{m}^{2}$ than plots that did not receive foramsulfuron. Plots seeded with $224 \mathrm{~kg} \mathrm{ha}^{-1}$ of perennial ryegrass seed and treated with foramsulfuron had only 5.1 plants per $\mathrm{m}^{2}$, which was a decrease of more than 50 plants when compared to the plots which did not receive the herbicide. This indicates that part of the stand observed one year after seeding was due to perennial ryegrass plants surviving through the summer. The limited effectiveness of foramsulfuron could be attributed to cooler temperatures during application, which should result in reduced absorption and/or translocation.

In trial two, more plants were counted one year after seeding than in trial one (Table 3 ). This difference could be due to increased latent germination one year after seeding in trial two or due to greater survival of perennial ryegrass plants through the summer in 2006 compared to 2005. In the summer of 2005, only $4.6 \mathrm{~cm}$ of rain fell between June 11 and July 12, while in $200623.9 \mathrm{~cm}$ of rain fell during this period. More perennial ryegrass plants were present than intermediate ryegrass plants in trial two one year after seeding. Plots seeded with $448 \mathrm{~kg} \mathrm{ha}^{-1}$ of perennial ryegrass had 207.7 plants per $\mathrm{m}^{2}$ while seeding with $448 \mathrm{~kg} \mathrm{ha}^{-1}$ of intermediate ryegrass resulted in 115.4 plants per $\mathrm{m}^{2}$ (Table 3). Applications of foramsulfuron did not significantly reduce ryegrass plants one year after seeding in trial two though numerical reductions were observed.

Analysis of the ryegrass comparison trial indicates that intermediate ryegrass seeded at $448 \mathrm{~kg} \mathrm{ha}^{-1}$ is an effective cultivar seeding rate combination to use for overseeding bermudagrass in the transition zone. Increasing the seeding rate from $224 \mathrm{~kg} \mathrm{ha}^{-1}$ to $448 \mathrm{~kg} \mathrm{ha}^{-1}$ of either ryegrass species significantly increased percent ryegrass cover during fall establishment and did not increase percent cover during the transitional spring-summer phase. These results are similar to those of Bornino et al. [17] who observed greater cover when the perennial ryegrass seeding rate was increased. A high percentage of ryegrass cover during the fall and receding of ryegrass in the spring are ideal for a bermudagrassryegrass transitional system. The intermediate ryegrass had 
Table 3: Persistence of two ryegrass species one year after seeding as affected by herbicide application in 2004 and 2005 for the first experiment. $^{\mathrm{a}}$

\begin{tabular}{|c|c|c|c|c|}
\hline \multirow{2}{*}{$\begin{array}{l}\text { Ryegrass } \\
\text { species }\end{array}$} & \multirow{2}{*}{ Seeding rate } & \multirow{2}{*}{ Foramsulfuron application } & \multicolumn{2}{|c|}{ Plants per $\mathrm{m}^{2}$} \\
\hline & & & Trial 1 & Trial 2 \\
\hline Intermediate & 224 & No & $10.8 \mathrm{~b}$ & $107.3 \mathrm{~b}$ \\
\hline Intermediate & 448 & No & $30.5 \mathrm{~b}$ & $115.4 \mathrm{~b}$ \\
\hline Perennial & 224 & No & $60.5 \mathrm{~b}$ & $127.1 \mathrm{~b}$ \\
\hline Perennial & 448 & No & $170.5 \mathrm{a}$ & $207.7 \mathrm{a}$ \\
\hline Intermediate & 224 & Yes & $1.2 \mathrm{~b}$ & $95.6 \mathrm{~b}$ \\
\hline Intermediate & 448 & Yes & $40.2 \mathrm{~b}$ & $152.3 \mathrm{ab}$ \\
\hline Perennial & 224 & Yes & $5.1 \mathrm{~b}$ & $130.7 \mathrm{~b}$ \\
\hline Perennial & 448 & Yes & $150.3 \mathrm{a}$ & $142.8 \mathrm{ab}$ \\
\hline
\end{tabular}

${ }^{a}$ Means within a column with the same letter are not significantly different according to the Fisher's protected least significant difference test at the 0.05 level.

equal or greater percent cover in the fall and winter dates when compared to perennial ryegrass; however, percent cover was almost nonexistent in the summer. Thus, intermediate ryegrass provided acceptable cover during periods when the bermudagrass was dormant. Subsequently, after bermudagrass resumed growth in spring, intermediate ryegrass did not persist at high levels by June, reducing the need for a transition aid herbicide. The April foramsulfuron applications removed half of the perennial ryegrass cover in trial one on the June rating date; however, the remaining perennial ryegrass cover would be unacceptable since it could restrict bermudagrass growth. Repeat applications of foramsulfuron may be required for acceptable perennial ryegrass removal.

The fall of 2005 was colder and had less rainfall than the fall of 2004. These environmental conditions probably reduced the number of seeds that germinated during the establishment of trial two. Subsequently, germination occurred one year later in trial two, which explains the increased plant counts. Minimal intermediate ryegrass plant cover was present in plots rated in June. Therefore, the intermediate ryegrass plants present one year after seeding would be attributed to latent germination and not summer survival. Perennial ryegrass plants might have survived the summer because applications of foramsulfuron lead to a reduction in perennial ryegrass counts one year after seeding in both trials for plots seeded at $448 \mathrm{~kg} \mathrm{ha}^{-1}$. Increasing the seeding rate from $224 \mathrm{~kg} \mathrm{ha}^{-1}$ to $448 \mathrm{~kg} \mathrm{ha}^{-1}$ increased ryegrass stand one year after seeding. Spring applications of foramsulfuron would be beneficial for removing perennial ryegrass that may persist past the summer.

3.2. Overseeding Species/Herbicide Timing Trial. Overseeding with intermediate or Italian ryegrass resulted in greater percent cover than with hybrid bluegrass. In trial one, overseeded grass cover observed in November was $74 \%$ for Italian ryegrass, $76 \%$ for intermediate ryegrass, and $20 \%$ for hybrid bluegrass (Table 4 ). In February for the same study, the ryegrasses continued to establish while the hybrid bluegrass cover only slightly increased. Cover ratings in February were $91 \%$ for annual ryegrass, $90 \%$ for intermediate ryegrass, and $24 \%$ for hybrid bluegrass. Similar trends were seen in trial two, though greater levels of the ryegrasses were able to persist until June in trial two. As in the previous trial, hybrid bluegrass did not establish to an acceptable level.

Foramsulfuron application did not have a significant effect on percent overseeded grass cover observed in June of trial one; however, some numerical reductions were noted. Intermediate ryegrass cover in plots that did not receive foramsulfuron applications was $6 \%$ (Table 4). Applications of foramsulfuron in March, April, and May reduced intermediate ryegrass cover to 3,1 , and 1 percent, respectively. In trial one, the application of foramsulfuron in March, April and May yielded lower hybrid bluegrass cover of 8,1 , and $6 \%$ percent, respectively, compared to $11 \%$ cover when no herbicide was applied. No Italian ryegrass survived to the June rating date in trial one.

Similar trends were seen in trial two, though Italian ryegrass was able to survive to the June rating date. Increased overseeded grass cover in trial two may be the result of increased rainfall during the spring-summer transition period. In trial one, only $4.6 \mathrm{~cm}$ of rain fell between June 11 and July 12, 2005, while in trial two, $23.9 \mathrm{~cm}$ of rain fell during this period in 2006. Hybrid bluegrass did not establish acceptably, though it still persisted into the summer. In trial two, application of foramsulfuron in May resulted in $14 \%$ Italian ryegrass cover in June, which was significantly less than the $23 \%$ Italian ryegrass cover in plots that did not receive foramsulfuron (Table 5). Foramsulfuron did not significantly reduce intermediate ryegrass cover in trial two. The lower than expected results from foramsulfuron in both the ryegrass comparison experiment (Tables 1 and 2) and in this experiment (Tables 4 and 5) were probably due to the lower than ideal temperatures at treatment time, as soil temperature at the different application timings ranged from 12 to $18^{\circ} \mathrm{C}$. A similar response was noted with foramsulfuron and other sulfonylurea herbicides, where applications were more effective at $26^{\circ} \mathrm{C}$ compared to $17^{\circ} \mathrm{C}$, or $21^{\circ} \mathrm{C}$ soil temperature [18].

Plant counts were greater in plots seeded with Italian ryegrass than in the other plots for trial one (Table 6). Italian ryegrass-seeded plots that did not receive foramsulfuron contained 168.2 plants per $\mathrm{m}^{2}$. Comparatively, none of the 
TABLE 4: Percent cover as affected by overseeded species and foramsulfuron application timing in 2004 for the second experiment. ${ }^{\mathrm{a}}$

\begin{tabular}{|c|c|c|c|c|}
\hline \multirow{2}{*}{ Species } & \multirow{2}{*}{ Foramsulfuron application } & \multicolumn{3}{|c|}{ Percent cover } \\
\hline & & November & February & June \\
\hline Intermediate ryegrass & None & $76 \mathrm{a}$ & $90 \mathrm{a}$ & $6 \mathrm{ab}$ \\
\hline Hybrid bluegrass & None & $20 c$ & $24 \mathrm{~b}$ & $11 \mathrm{a}$ \\
\hline Italian ryegrass & None & $74 \mathrm{a}$ & $91 \mathrm{a}$ & $0 \mathrm{~b}$ \\
\hline Intermediate ryegrass & March & $80 \mathrm{a}$ & $89 \mathrm{a}$ & $3 \mathrm{~b}$ \\
\hline Hybrid bluegrass & March & $20 \mathrm{c}$ & $28 \mathrm{~b}$ & $8 \mathrm{ab}$ \\
\hline Italian ryegrass & March & $78 \mathrm{a}$ & $91 \mathrm{a}$ & $0 \mathrm{~b}$ \\
\hline Intermediate ryegrass & April & $80 \mathrm{a}$ & $89 \mathrm{a}$ & $1 \mathrm{~b}$ \\
\hline Hybrid bluegrass & April & $20 c$ & $29 \mathrm{~b}$ & $1 \mathrm{~b}$ \\
\hline Italian ryegrass & April & $74 \mathrm{a}$ & $90 \mathrm{a}$ & $0 \mathrm{~b}$ \\
\hline Intermediate ryegrass & May & $81 \mathrm{a}$ & $88 \mathrm{a}$ & $1 \mathrm{~b}$ \\
\hline Hybrid bluegrass & May & $20 c$ & $26 \mathrm{~b}$ & $6 \mathrm{ab}$ \\
\hline Italian ryegrass & May & $56 \mathrm{~b}$ & $89 \mathrm{a}$ & $0 \mathrm{~b}$ \\
\hline
\end{tabular}

${ }^{a}$ Means within a column with the same letter are not significantly different according to the Fisher's protected least significant difference test at the 0.05 level.

TABLE 5: Percent cover of overseeded species as affected by foramsulfuron application timing in 2005 for the second experiment. ${ }^{\mathrm{a}}$

\begin{tabular}{|c|c|c|c|c|}
\hline \multirow{2}{*}{ Species } & \multirow{2}{*}{ Foramsulfuron application } & \multicolumn{3}{|c|}{ Percent cover } \\
\hline & & November & February & June \\
\hline Intermediate ryegrass & None & $56 \mathrm{a}$ & $68 \mathrm{a}$ & $20 \mathrm{ab}$ \\
\hline Hybrid bluegrass & None & $8 \mathrm{~b}$ & $10 \mathrm{~b}$ & $10 \mathrm{cde}$ \\
\hline Italian ryegrass & None & $58 \mathrm{a}$ & $73 \mathrm{a}$ & $23 \mathrm{a}$ \\
\hline Intermediate ryegrass & March & $60 \mathrm{a}$ & $71 \mathrm{a}$ & $23 \mathrm{a}$ \\
\hline Hybrid bluegrass & March & $3 \mathrm{~b}$ & $5 \mathrm{~b}$ & $6 \mathrm{e}$ \\
\hline Italian ryegrass & March & $54 \mathrm{a}$ & $70 \mathrm{a}$ & $16 \mathrm{bcd}$ \\
\hline Intermediate ryegrass & April & $55 \mathrm{a}$ & $70 \mathrm{a}$ & $19 \mathrm{abc}$ \\
\hline Hybrid bluegrass & April & $2 \mathrm{~b}$ & $4 \mathrm{~b}$ & $7 \mathrm{e}$ \\
\hline Italian ryegrass & April & $56 \mathrm{a}$ & $71 \mathrm{a}$ & $19 \mathrm{abc}$ \\
\hline Intermediate ryegrass & May & $57 \mathrm{a}$ & $69 \mathrm{a}$ & $18 \mathrm{abc}$ \\
\hline Hybrid bluegrass & May & $5 \mathrm{~b}$ & $7 \mathrm{~b}$ & $8 \mathrm{e}$ \\
\hline Italian ryegrass & May & $53 \mathrm{a}$ & $68 \mathrm{a}$ & $14 \mathrm{~cd}$ \\
\hline
\end{tabular}

plots seeded with hybrid bluegrass or intermediate ryegrass had more than 68 plants per $\mathrm{m}^{2}$. Foramsulfuron application did not have an impact on plant counts one year after seeding in trial one, suggesting that plants observed one year later were due to new germination and not summer survival of plants that germinated the previous fall.

More intermediate ryegrass plants either germinated one year after seeding or survived the summer in trial two were compared to trial one. Plots seeded with intermediate ryegrass that did not receive foramsulfuron had 112 plants per $\mathrm{m}^{2}$ (Table 6 ). Foramsulfuron reduced intermediate ryegrass plants per $\mathrm{m}^{2}$ to 90,65 , and 60 when applied in March, April, and May, respectively, suggesting that some of the plants in untreated plots had survived the summer. In study two, Italian ryegrass had the most plants per $\mathrm{m}^{2}$. Plots seeded with Italian ryegrass had 180 plants per $\mathrm{m}^{2}$. Applications of foramsulfuron did not reduce Italian ryegrass plant counts, suggesting new germination. Plots seeded with hybrid bluegrass had significantly lower plant counts when compared to the two ryegrass species.

Hybrid bluegrass was not able to establish as quickly as intermediate or Italian ryegrass. Inability to establish in the fall and transition out in the spring make hybrid bluegrass undesirable for overseeding bermudagrass. The ability of Italian ryegrass to survive into the summer in trial two may be due to cooler temperatures and more rainfall in the summer of trial two. Foramsulfuron applied in May of trial two reduced Italian ryegrass percent cover significantly in June when compared to the plots that did not receive foramsulfuron. Italian ryegrass should transition out of the turfgrass soon after bermudagrass resumes growth, which was apparent in trial one. In the event of high rainfall and cooler temperature (as observed in trial two) in the months of April and May, applications of foramsulfuron in late May could be made to enhance removal of overseeded Italian ryegrass and intermediate ryegrass. Plots seeded with 
TABle 6: Persistence of three overseeded species one year after seeding as affected by foramsulfuron application timing in 2004 and 2005 for the second experiment. ${ }^{\mathrm{a}}$

\begin{tabular}{lccc}
\hline Species & $\begin{array}{c}\text { Foramsulfuron } \\
\text { application }\end{array}$ & \multicolumn{2}{c}{ Plants per $\mathrm{m}^{2}$} \\
& Trial 1 & Trial 2 \\
\hline Intermediate ryegrass & None & $68.2 \mathrm{~b}$ & $112.2 \mathrm{a}$ \\
Hybrid bluegrass & None & $3.7 \mathrm{~b}$ & $9.5 \mathrm{~b}$ \\
Italian ryegrass & None & $168.2 \mathrm{~b}$ & $180.7 \mathrm{a}$ \\
Intermediate ryegrass & March & $30.0 \mathrm{~b}$ & $90.3 \mathrm{a}$ \\
Hybrid bluegrass & March & $0.2 \mathrm{~b}$ & $8.8 \mathrm{~b}$ \\
Italian ryegrass & March & $413.1 \mathrm{a}$ & $178.9 \mathrm{a}$ \\
Intermediate ryegrass & April & $55.7 \mathrm{~b}$ & $65.4 \mathrm{a}$ \\
Hybrid bluegrass & April & $3.4 \mathrm{~b}$ & $11.1 \mathrm{~b}$ \\
Italian ryegrass & April & $183.4 \mathrm{~b}$ & $180.1 \mathrm{a}$ \\
Intermediate ryegrass & May & $40.1 \mathrm{~b}$ & $60.4 \mathrm{a}$ \\
Hybrid bluegrass & May & $18.1 \mathrm{~b}$ & $17.2 \mathrm{~b}$ \\
Italian ryegrass & May & $183.2 \mathrm{~b}$ & $170.3 \mathrm{a}$ \\
\hline
\end{tabular}

${ }^{a}$ Means within a column with the same letter are not significantly different according to the Fisher's protected least significant difference test at the 0.05 level.

Italian ryegrass had the most plants per $\mathrm{m}^{2}$ one year after seeding in both trials, which would be attributed to latent germination and not summer survival. Intermediate ryegrass color was compared favorably with hybrid bluegrass while Italian ryegrass had the lowest color rating (Data not shown).

Italian, intermediate, and perennial ryegrasses are behaving primarily as winter annuals in southeastern Virginia when overseeded into bermudagrass. A low density of perennial, intermediate and Italian ryegrass persisting one year after seeding may necessitate changes in management practices to remove these species if overseeding is not done annually. As observed in these trials, environmental factors play a critical role in the overseeding process. Although the same protocols were duplicated in both years of the experiments, significant differences between the years were observed. These differences were most likely because of variations in rainfall and temperatures during the germination and transition periods. Monitoring of rainfall and irrigation should be practiced in order to ensure successful establishment and to ease transition of the overseeded turfgrass. Intermediate ryegrass appears to be a useful option for overseeding bermudagrass because of its acceptable cover in spring combined with its transitional ability during the elimination phase. Reduction in perennial ryegrass's persistence is dependent on drier environmental conditions rather than cool and wet conditions and the use of an herbicide such as foramsulfuron in order to transition adequately. Applications, though, should be made under warm soil temperatures (above $18^{\circ} \mathrm{C}$ ) since this herbicide is not as effective when applied in cooler temperatures. Willis showed that perennial ryegrass control with foramsulfuron was significantly lower when applied at soil temperatures below $18^{\circ} \mathrm{C}$ compared to warmer soil conditions [19]. Latent germination one year after seeding and a lighter green color are characteristics that make Italian ryegrass a less desirable overseeding species compared to intermediate or perennial ryegrass.

\section{References}

[1] M. D. Richardson, "Morphology, turf quality, and heat tolerance of intermediate ryegrass," HortScience, vol. 39, no. 1, pp. 170-173, 2004.

[2] A. J. Turgeon, Turfgrass Management, Prentice-Hall, Englewood Cliffs, NJ, USA, 3rd edition, 1991.

[3] A. E. Dudeck and C. H. Peacock, "Effects of several overseed ryegrass on turf quality, traffic tolerance, and ball roll," in Proceedings of the 4th International Turfgrass Research Conference, R. W. Sheard, Ed., pp. 75-81, Guelph, Canada, 1980.

[4] R. E. Schmidt and J. F. Shoulders, "Seasonal performance of selected temperate turfgrass over-seeded on bermudagrass turf for winter sports," in Proceedings of the 3rd International Turfgrass Research Conference, J. B. Beard, Ed., pp. 75-86, Madison, Wis, USA, 1977.

[5] C. S. Hoveland, W. B. Anthony, J. A. McGuire, and J. G. Starling, "Beef cow-calf performance on coastal bermudagrass overseeded with winter annual clovers and grasses," Agronomy Journal, vol. 70, pp. 418-420, 1978.

[6] B. J. Johnson, "Transition from overseeded cool-season to warm-season grass with pronamide," Weed Science, vol. 24, pp. 309-311, 1975.

[7] J. M. Zhang, J. Luo, J. Zhang, S. S. Lin, S. X. Mo, and L. J. Lu, "Winter overseeding zoysiagrass sports turf with cool-season turfgrasses in Southern China," Acta Horticulturae, vol. 783, pp. 85-95, 2008.

[8] L. R. Nelson, R. White, M. C. Engelke, J. Crowder, M. D. Lazar, and D. Singh, "Registration of 'Panterra' annual ryegrass," Crop Science, vol. 44, pp. 1873-1874, 2004.

[9] B. P. Horgan and F. H. Yelverton, "Removal of perennial ryegrass from overseeded bermudagrass using cultural methods," Crop Science, vol. 41, no. 1, pp. 118-126, 2001.

[10] C. T. Bryson and M. S. DeFelice, Eds., Weeds of the South, Univ. Georgia Press, Athens, Greece, 2009.

[11] J. C. Read, J. A. Reinert, P. F. Colbaugh, and W. E. Knopp, "Registration of Reveille hybrid bluegrass," Crop Science, vol. 39, p. 590, 1999.

[12] W. E. Knoop, "Enhancing spring transition," Lawn Servicing, vol. 4, p. 11, 1987.

[13] A. R. Mazur and J. S. Rice, "Impact of overseeding bermudagrass with various amounts of perennial ryegrass for winter putting turf," HortScience, vol. 34, no. 5, pp. 864-866, 1999.

[14] T. Samples and J. Sorochan, "Overseeding bermudagrass with perennial ryegrass," UT extension. W 161J-3. 2 p., 2008.

[15] S. B. Powles and P. D. Howat, "Herbicide-resistant weeds in Australia,” Weed Technology, vol. 4, pp. 178-185, 1990.

[16] J. B. Beam, W. L. Barker, and S. D. Askew, "Italian ryegrass (Lolium multiflorum) control in newly seeded tall fescue," Weed Technology, vol. 19, no. 2, pp. 416-421, 2005.

[17] B. F. Bornino, C. A. Bigelow, and Z. J. Reicher, "Strategy and rate affects success of perennial ryegrass overseeding into bermudagrass athletic fields located on the edge of the transition zone," Applied Turfgrass Science, 2010.

[18] K. C. Hutto, J. M. Taylor, and J. D. Byrd, "Soil temperature as an application indicator for perennial ryegrass control," Weed Technology, vol. 22, no. 2, pp. 245-248, 2008. 
[19] J. Willis, Cold temperature influence on perennial ryegrass (Lolium perenne) control with flazasulfuron, foramsulfuron, and trifloxysulfuron-sodium, Ph.D. thesis, Virginia Tech., 2008, http://scholar.lib.vt.edu/theses/available/etd-11112008135045/unrestricted/WillisDissertation12_02_08.pdf. 


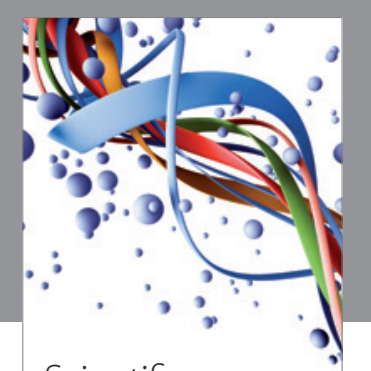

Scientifica
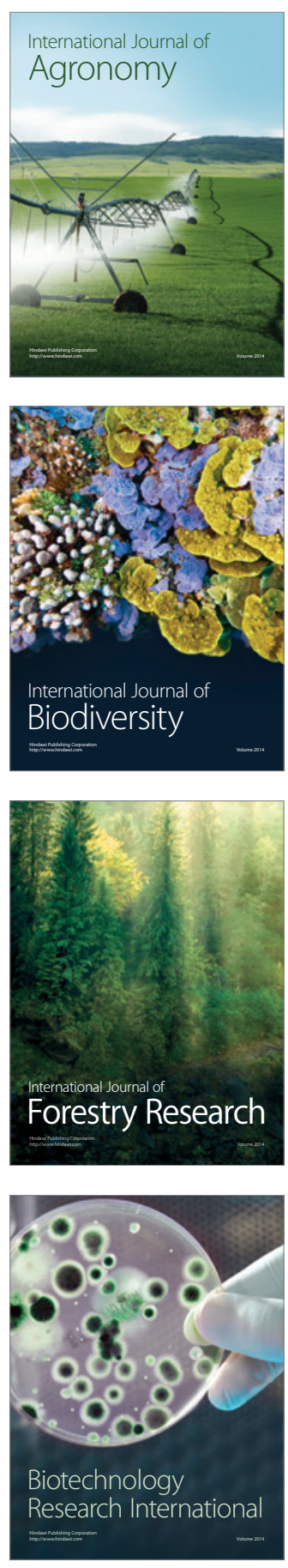
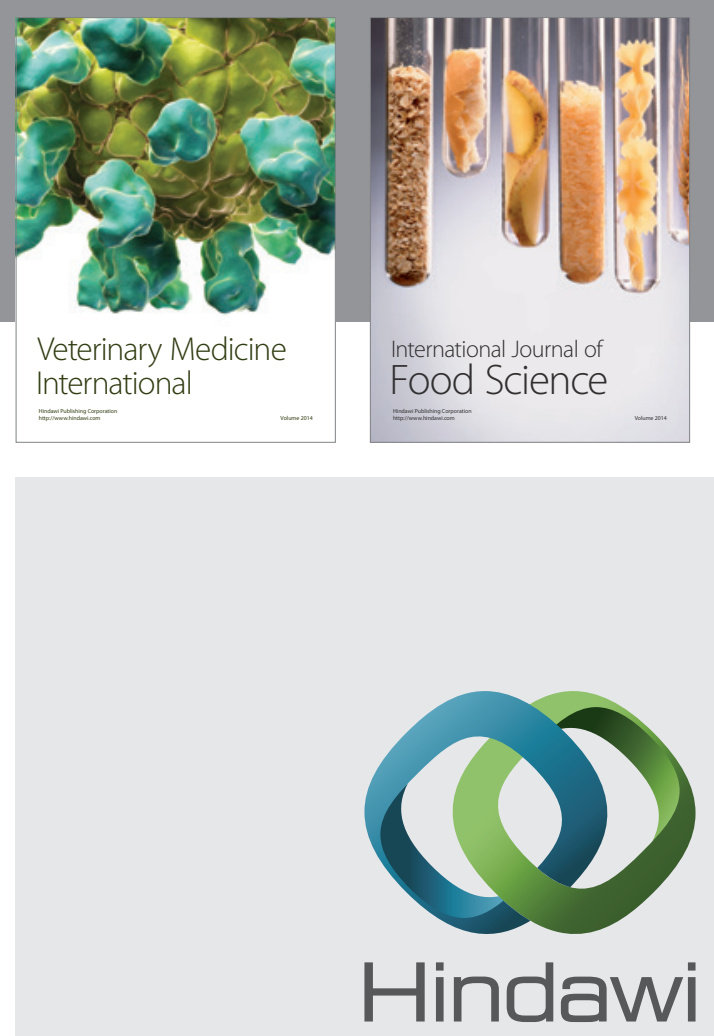

Submit your manuscripts at

http://www.hindawi.com
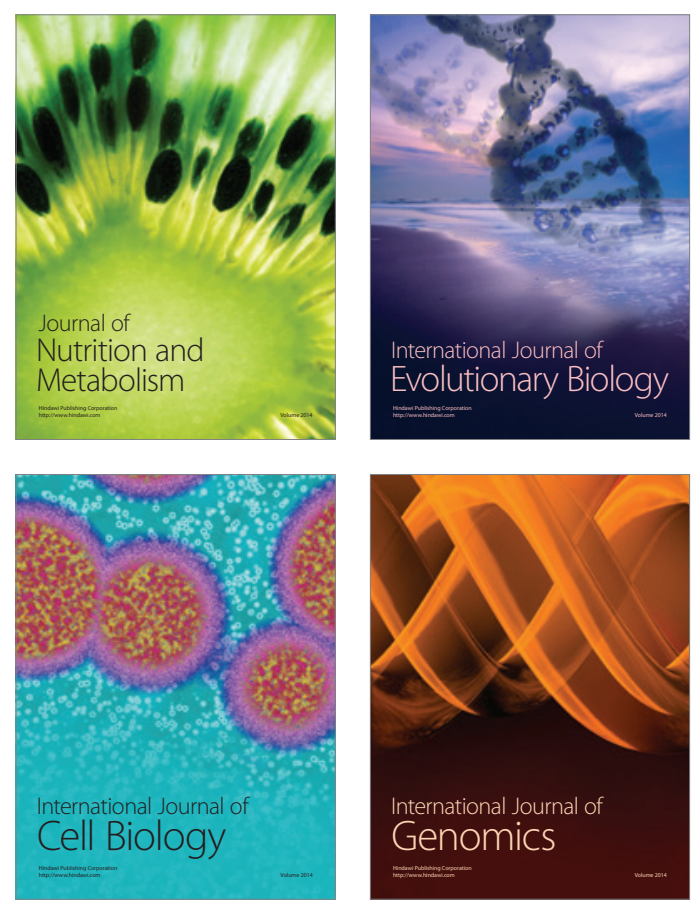
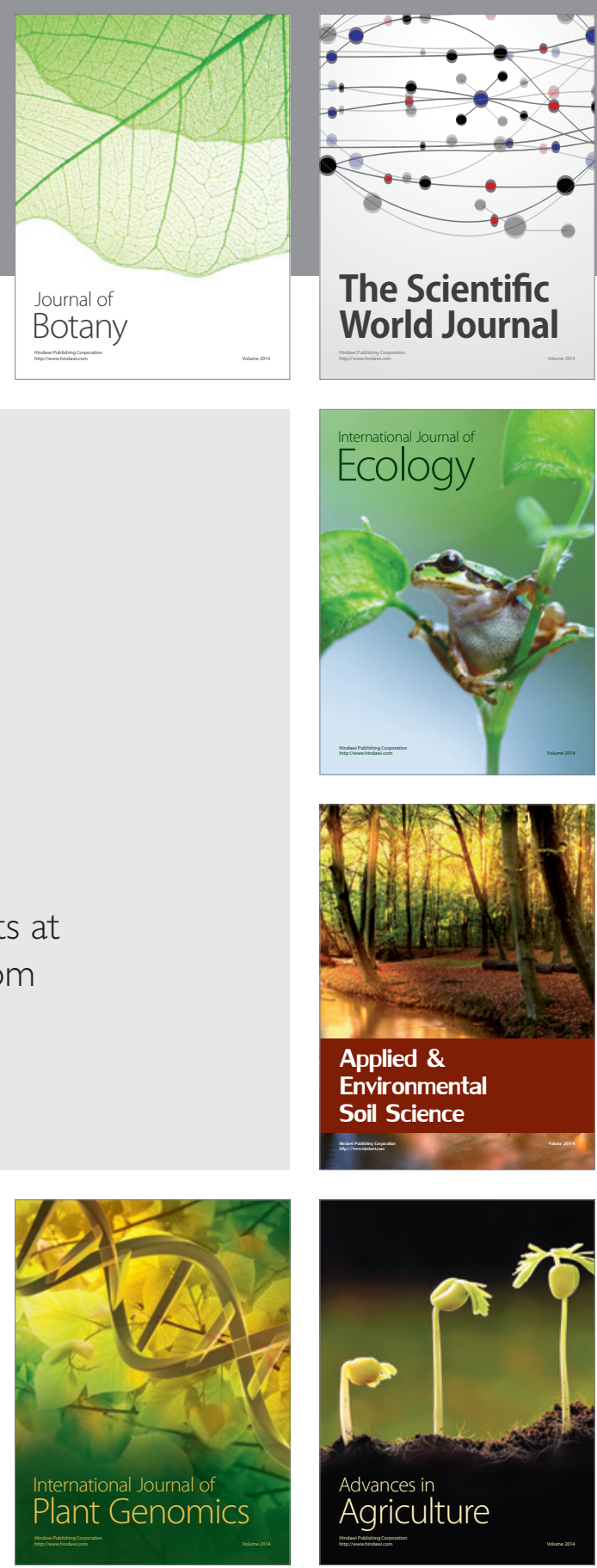

The Scientific World Journal
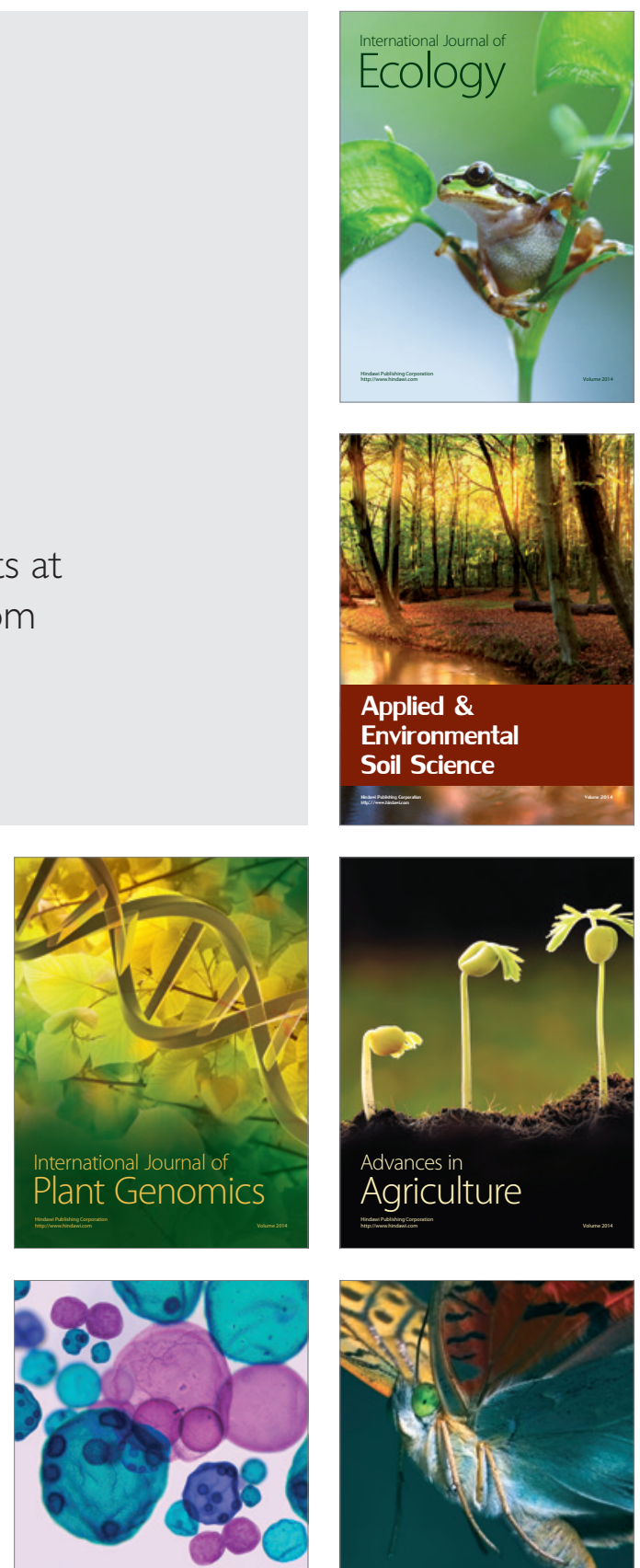

International Journal of Microbiology

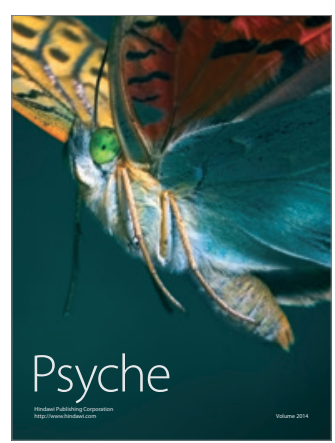

